\title{
PIDANA PENGAWASAN TERHADAP ANAK YANG BERHADAPAN DENGAN HUKUM DALAM SISTEM PEMIDANAAN DI INDONESIA
}

Oleh:

I Putu Suwarsa

\begin{abstract}
This research was conducted with the normative approach legislation. Factual approach, analytical approach to the legal concept of a comparative approach in the criminal judicial oversight of Children in Conflict with the Law in the criminal sistem in Indonesia.

In formulating criminal law criminal policy oversight of Children in Conflict with the Law in the guidance sistem of positive law in Indonesia, consists of 3 major topics: First, the substance of Children in Conflict with the Law into law in Indonesia, Second, Determination of sanctions / penalties against Children in Conflict with the Law in Indonesia's criminal law policy, Third, criminal oversight of Children in Conflict with the Law and its relevance to the theory of punishment in modern criminal law in Indonesia. Criminal oversight of Children in Conflict with the Law as the integrative goals of punishment in accordance with the ideas and correctional sistem discussed 3 subjects namely: First, criminal oversight of anal naughty review of aspects of the integrative theory of punishment, Second, Criminal oversight of Children in Conflict with the Law review of aspects of correctional sistem, Third, Criminal oversight of Children in Conflict with the Law in terms of aspects of legal protection and benefit of the criminal law requirement for social welfare (children). And its application by all law enforcement components and related institutions involved in handling cases of children in conflict with the law in coaching children in prison.
\end{abstract}

Keywords: Probation; Children in Conflict with the Law; Punishment Sistem.

\section{PENDAHULUAN}

Kecendrungan meningkatnya

kualitas maupun kuantitas pelanggaran terhadap ketertiban maupun ketentuan undang-undang oleh pelaku-pelaku muda usia, atau dengan kata lain meningkatnya kenakalan anak yang mengarah pada tindakan kriminal, mendorong untuk lebih banyak memberikan perhatian akan penanggulangan atau penanganannya. Anak yang melakukan kejahatan seharusnya juga dilindungi dan dibina. Dalam menghadapi masalah Anak yang Berhadapan dengan Hukum, mulai dari pembinaan, pendidikan, dan pengembangan perilaku anak bukan hanya merupakan tanggung jawab orang tua melainkan masyarakat sekitar. Apabila kenakalan anak tidak ditanggulangi secara serius maka hal ini berarti akan menghancurkan generasi muda penerus cita-cita bangsa. Jika 
tidak ditangani sejak dini maka kejahatan anak itu berkembang makin luas, anak-anak yang melakukan kejahatan tersebut akan tumbuh dewasa dan berpotensi melakukan kejahatan yang lebih serius.

Untuk mengetahui penyebab kenakalan anak yang bertentangan dengan norma-norma yang ada dalam masyarakat disamping norma hukum, perlu dipahami dalam rangka untuk penanggulangannya.

Dalam kaitan perlindungan terhadap hak-hak anak maka dalam konvensi Hak Anak Pasal 37 b dinyatakan bahwa tidak seorang anak pun dapat dirampas kemerdekaannya secara tidak sah atau sewenang-wenang. Penangkapan, penahanan, dan pemenjaraan seorang anak haruslah sesuai dengan hukum dan hanya diterapkan sebagai upaya terakhir untuk jangka waktu sesingkat-singkatnya. Kegiatan perlindungan anak merupakan suatu tindakan hukum yang membawa akibat hukum sehingga diperlukan adanya jaminan hukum bagi kegiatan perlindungan anak. ${ }^{1}$

Pengaturan tentang pidana bersyarat dalam KUHP yang berlaku

\footnotetext{
${ }^{1}$ Arif Gosita, 1989, Masalah Perlindungan Anak, Akademika Pressindo, Jakarta, hal. 18.
}

sekarang belum dapat digunakan secara lebih efektif sebagai sarana alternatif penerapan pidana penjara, khususnya pidana penjara waktu pendek. Salah satu bentuk alternatif pidana perampasan kemerdekaan (alternatives to imprisonment) yang lain ialah dengan diadakannya jenis sanksi yang dikenal dengan istilah probation and judicial supervision (The Tokyo Rules-Rule 8.2 huruf h). Hal ini juga sesuai dengan Konggres PBB ketiga di Stockhlom pada tahun 1965 tentang Pencegahan Kejahatan dan Pembinaan Narapidana, yang juga memfokuskan pada diskusidiskusi tentang pidana pengawasan (probation) untuk orang dewasa dan tindakan-tindakan lain yang bersifat noninstitusional. $^{2}$

Menurut Muladi, istilah probation/pidana pengawasan dalam pengertian modern mempunyai arti sebagai suatu sistem yang berusaha untuk mengadakan rehabilitasi terhadap seseorang yang terbukti melakukan tindak pidana, dengan cara mengembalikannya ke masyarakat selama suatu periode pengawasan. ${ }^{3}$

Anak yang dijatuhi pidana pengawasan umumnya berada diluar

\footnotetext{
${ }^{2}$ Muladi dan Barda Nawawi Arief, 1998, Teori-teori dan Kebijakan Pidana, Alumni Bandung, hal. 84.

${ }^{3}$ Ibid, hal. 155-156
} 
Lembaga Pemasyarakatan sehingga terkesan bebas dari hukuman karena anak tersebut berada dalam lingkungan keluarganya dan tetap dapat melakukan aktivitasnya sehari-hari seperti Pemasyarakatan (BAPAS) yang memiliki tugas-tugas (pasal 65 UU Sistem Peradilan Pidana Anak).

Dari paparan di atas maka terdapat dua permasalahan pokok yang akan dibahas, yaitu : (a) Bagaimana kebijakan hukum pidana memformulasikan pidana pengawasan terhadap Anak yang Berhadapan dengan Hukum dalam sistem pemidanaan didalam hukum positif Indonesia ?; (b) Bagaimana pidana pengawasan terhadap Anak yang Berhadapan dengan Hukum sesuai dengan ide pemasyarakatan yang ditentukan dalam Undang Undang Nomor 12 Tahun 1995 ?

\section{METODE PENELITIAN}

Jenis penelitian ini tergolong kedalam penelitian hukum normatif yang dilengkapi dengan bahan hukum kepustakaan maka titik berat penelitian ini mempergunakan bahan hukum bukan data, sehingga data primer yang dipergunakan hanya bersifat memperkuat, melengkapi dan menunjang, kemudian sumber data dilakukan melalui sumber data bersekolah, bermain dan lain sebagainya. Padahal anak tersebut tetap diawasi (oleh penuntut umum) dan dibimbing oleh Pembimbing Kemasyarakatan (PK) dari Balai

kepustakaan (library research) yang terdiri dari bahan hukum primer dan bahan hukum sekunder. ${ }^{4}$

Adapun bahan hukum primer yang digunakan terutama berpusat dan bertitik tolak pada peraturan perundangundangan yang berlaku di Indonesia seperti UU nomor 4 tahun 1979, UU nomor 8 tahun 1981, UU nomor 12 tahun 1995, UU nomor 23 tahun 2002, dan UU nomor 11 tahun 2012.

\section{III.HASIL DAN PEMBAHASAN}

3.1 Kebijakan hukum pidana memformulasikan pidana pengawasan terhadap anak yang berhadapan dengan hukum dalam sistem pembinaan didalam hukum positif Indonesia

1. Substansi Terhadap Anak yang Berhadapan dengan Hukum dalam Kebijakan Hukum di Indonesia

Setelah diterbitkannya Undangundang Nomor 11 Tahun 2012 pengganti Undang-undang Nomor 3 Tahun 1997,

\footnotetext{
4 Soemitro, Ronny Hanitijo, 1994, Metodologi Penelitian Hukum dan Jurimetri, Ghalia Indonesia, Jakarta, hal. 11.
} 
telah diatur secara khusus tentang hukum pidana materiil, hukum pidana formil, dan hukum pelaksanaan pidana bagi anak yang telah melakukan kenakalan. Oleh karena itu, UU No. 11/2012 merupakan hukum yang khusus (lex spesialis) dari hukum yang umum (lex generalis) yang tertuang dalam Kitab Undang-undang Hukum Pidana (KUHP) dan Kitab Undang-undang Hukum Acara Pidana (KUHAP). ${ }^{5}$

Sebelum memahani pengertian Anak yang Berhadapan dengan Hukum, terlebih dahulu perlu memahami batasan umur anak yang diajukan ke sidang anak. Secara eksplisit dapat dilihat pada Pasal 1 butir 3 .

Pasal 1 butir 3

Anak yang berkonflik dengan hukum yang selanjutnya disebut anak adalah anak yang telah berumur 12 (dua belas) tahun, tetapi belum berumur 18 (delapan belas) tahun yang diduga melakukan tindak pidana.

Dari pasal di atas tersebut menunjukkan bahwa yang disebut sebagai anak yang dapat diperkarakan ke sidang anak hanyalah anak yang berumur 12 tahun sampai 18 tahun dan belum pernah kawin. Anak yang belum mencapai 18 tahun tetapi telah menikah,

5 Nashriana, 2011. Perlindungan Hukum Pidana bagi anak di Indonesia. PT.RajaGrafindo Persada, Jakarta, hlm. 75 secara a contrario tidak dapat diajukan ke sidang anak, tetapi ke sidang orang dewasa berdasarkan KUHP dan KUHAP.

Tentang pengertian Anak yang Berhadapan dengan Hukum, Pasal 1 butir 2 UU No.11/2012 tentang Sistem Peradilan Pidana Anak mengandung pengertian:

Anak yang Berhadapan dengan Hukum adalah anak yang berkonflik dengan hukum, anak yang menjadi korban tindak pidana, dan anak yang menjadi saksi tindak pidana.

Walaupun Undang-undang Sistem Peradilan Pidana Anak tidak merumuskan lebih jelas tentang tindak pidana yang dapat dilanggar bagi anak, karena dalam Penjelasan pasal pun dirumuskan "cukup jelas", akan tetapi dapat dipahami bahwa tindak pidana yang dimaksud adalah selain tindak pidana yang dirumuskan dalam KUHP, semisal: UU tentang Narkotika, UU Psikotropika, UU Hak Cipta dan sebagainya.

Dalam UU Sistem Peradilan Pidana Anak Pasal 1 butir 1 yang dimaksud Sistem Peradilan Pidana Anak adalah keseluruhan proses penyelesaian perkara Anak yang Berhadapan dengan Hukum, mulai tahap penyelidikan sampai dengan tahap pembimbingan setelah menjalani pidana. 


\section{Penetapan}

Sanksi/Hukuman

Terhadap Anak yang Berhadapan

dengan Hukum Dalam Kebijakan

\section{Hukum di Indonesia}

Perumusan Sanksi Pidana dan

Sanksi Tindakan ini menunjukan bahwa

UU No.11/2012 tentang Sistem Peradilan

Pidana Anak telah menganut apa yang

disebut dengan Double Track Sistem.

Dengan kata lain, UU ini telah secara

eksplisit mengatur tentang jenis sanksi

Pidana dan sanksi Tindakan sekaligus.

Menurut Muladi (2002) ${ }^{6}$, penggunaan

sistem dua jalur (Zweipurigkeit)

merupakan konsekuensi dianutnya Aliran

Neo Klasik. ${ }^{7}$ Pemikiran bahwa

pendekatan tradisional seolah-olah sistem

Tindakan hanya dikenakan bagi orang yang tidak mampu harus ditinggalkan.

Dalam pembangunan hukum pidana positif Indonesia, memang telah diakui keberadaan sanksi tindakan selain sanksi pidana, walaupun dalam KUHP menganut Single Track Sistem yang

${ }^{6}$ Muladi, 2002. Hak Asasi Manusia Politik dan Sistem Peradilan Pidana, Cetakan II. Badan Penerbit Universitas Diponegoro, Semarang, hlm. 156

7 Dalam Aliran Neo Klasik, berusaha untuk memanfaatkan kelebihan kedua aliran sebelumnya (aliran Klasik dan aliran Modern) dan meninggalkan kelemahan yang ada. Asas pembalasan diperbaiki dengan teori kesalahan yang bertumpu pada usia, aptologi, dan pengaruh lingkungan. Dikembangkan alasan-alasan yang memperingan dan memperberat pemidanaan; kesaksian ahli (expert testimony) ditonjolkan; diaturnya sistem dua jalur (Double Track Sistem). hanya mengatur tentang satu jenis saja yaitu sanksi pidana (Pasal 10 KUHP). Pengancaman Sanksi Tindakan dalam UU 11/2012 menunjukkan bahwa ada sarana lain selain pidana (penal) sebagai sarana dalam penanggulangan kejahatan.

Sanksi pidana sesungguhnya bersifat reaktif terhadap suatu perbuatan, sedangkan sanksi tindakan lebih bersifat antipatif terhadap pelaku perbuatan tersebut. Jika fokus sanksi pidana tertuju pada perbuatan salah seseorang lewat pengenaan penderitaan (agar yang bersangkutan menjadi jera); maka fokus sanksi tindakan terarah pada upaya memberi pertolongan agar pelaku berubah.

Disini terlihat bahwa sanksi pidana lebih menekankan unsur pembalasan (pengimbalan). Ia merupakan penderitaan yang sengaja diberikan kepada seorang pelanggar. Sedangkan sanksi tindakan bersumber dari ide dasar perlindungan masyarakat dan pembinaan atau perawatan di pembuat. Atau seperti yang dikatakan J.E. jonkers (1987), bahwa sanksi pidana dititikberatkan pada pidana yang diterapkan untuk kejahatan yang dilakukan, sedangkan sanksi 
tindakan mempunyai tujuan yang bersifat sosial. $^{8}$

Lebih lanjut, terkait dengan sanksi bagi Anak yang Berhadapan dengan Hukum yang berupa sanksi pidana, terdiri atas pidana pokok dan pidana tambahan. Untuk pidana pokok, ada 5 (lima) macam sebagaimana yang ditetapkan pada Pasal 71 UU Sistem Peradilan Pidana Anak (SPPA) ini ditentukan bahwa pidana pokok bagi anak terdiri atas:

a. Pidana peringatan, yakni pidana ringan yang tidak mengakibatkan pembatasan kebebasan anak;

b. Pidana dengan syarat meliputi: pembinaan di luar lembaga, pelayanan masyarakat, atau pengawasan,

c. Pelatihan kerja;

d. Pembinaan dalam lembaga;

e. Penjara

Selain itu juga terdapat pidana tambahan yang terdiri atas perampasan keuntungan yang diperoleh dari tindak pidana atau pemenuhan kewajiban adat. Apabila dalam hukum materiil diancam pidana kumulatif berupa penjara dan denda, pidana denda diganti dengan pelatihan kerja. Hal yang ditekankan juga

${ }^{8}$ J.E. Jonkers, 1987. Buku Pedoman Hukum Pidana Hindia Belanda. Bina Aksara, Jakarta, hlm, 350 . bahwa pidana yang dijatuhkan kepada anak dilarang melanggar harkat dan martabat anak.

Anak dijatuhi pidana di Lembaga Pemasyarakatan Khusus Anak (LPKA) apabila keadaan dan perbuatan anakk akan membahayakan masyarakat. Pidana penjara yang dapat dijatuhkan kepada anak paling lama 1/2 (satu perdua) dari maksimum ancaman pidana penjara bagi orang dewasa. Untuk pembinaan di LPKA dilaksanakan sampai anak berumur 18 (delapan belas) tahun. Sementara itu, jika tindak pidana yang dilakukan anak merupakan tindak pidana yang diancam dengan pidana mati atau pidana penjara seumur hidup, pidana yang dijatuhkan adalah pidana penjara paling lama 10 (sepuluh) tahun.

Sementara itu, untuk tindakan kepada anak meliputi:

a. Pengembalian kepada orang tua/wali;

b. Penyerahan kepada seseorang;

c. Perawatan di rumah sakit jiwa;

d. Perawatan di LPKS;

e. Kewajiban mengikuti pendidikan formal dan/atau pelatihan yang diadakan oleh pemerintah atau badan swasta;

f. Pencabutan surat izin mengemudi; dan/atau

g. Perbaikan akibat tindak pidana. 
Tindakan tersebut dapat diajukan oleh

Penuntut Umum dalam tuntutannya, kecuali tindak pidana diancam dengan pidana penjara paling singkat 7 (tujuh) tahun. Dalam UU Sistem Peradilan Pidana Anakk ini ditentukan bahwa anak yang belum berusia 14 (empat belas tahun) hanya dapat dikenai tindakan.

\section{Pidana Pengawasan Terhadap} Anak yang Berhadapan dengan Hukum dan Relevansinya Dengan

Teori Pemidanaan Dalam Hukum

Pidana Modern di Indonesia

Pemidanaan atau sering juga disebut dengan pemberian pidana (strafteemeting), menurut Soedarto dalam bukunya Hukum dan Hukum Pidana memberikan dua makna, yakni:

1. dalam arti umum: pemberian pidana (poena) oleh pembentuk undang-undang adalah hal penetapan sanksi hukum pidana (Pemberian pidana in Abstracto)

Batasan ini didasarkan penganutan asas Legalitas dari zaman Aufklarung yang menentukan bahwa dalam pengenaan pidana diperlukan undang-undang terlebih dahulu. Petunjuk undang-undanglah yang menetapkan peraturan tentang pidananya, tidak hanya tentang crime atau delictum-nya ialah tentang perbuatan mana yang dapat dikenakan pidana.

2. dalam arti khusus/konkret: menyangkut berbagai badan atau lembaga yang mendukung dan melaksanakan stelsel sanksi hukum pidana tersebut (Pemberian pidana in Concreto $)^{9}$. Sebelum berlakunya UU Sistem Peradilan Pidana Anak, hukum materiil anak yang juga termasuk pemidanaan dirumuskan dalam Pasal 45, 46, dan 47 KUHP.

Apabila ancaman hukuman yang disediakan terhadap anak menurut KUHP dibandingkan dengan ancaman hukuman anak dalam UU Sistem Peradilan Pidana Anak mengancam lebih ringan.

Dalam UU Sistem Peradilan Pidana Anak, pola pemidanaannya dapat dilihat sebagai berikut: Dalam UU Sistem Peradilan Pidana Anak, pola pemidanaannya dapat dilihat pada Pasal 20, Pasal 21, Pasal 32, Pasal 33, pasal 34, Pasal 35, Pasal 37, Pasal 38, pasal 39, pasal 40, pasal 71, pasal 73, Pasal 77, Pasal 82, pasal 85, dan pasal 86.

\subsection{Pidana pengawasan terhadap anak yang berhadapan dengan hukum sebagai tujuan pemidanaan yang integratif sesuai dengan ide dan sistem pemasyarakatan}

\section{Pidana pengawasan terhadap anak} yang berhadapan dengan hukum

\footnotetext{
${ }^{9}$ Sudarto, 1975. Hukum Pidana. Badan Penyedia Bahan Kuliah Fakultas Hukum UNDIP, Semarang, hlm. 3
} 


\section{ditinjau dari aspek teori pemidanaan yang integratif}

Pelaksanaan pembinaan anak didik mempunyai metode pembinaan yang berbeda dengan pembinaan narapidana dewasa, hal ini terkait dengan karakteristik yang melekat pada diri anak. Anak merupakan individu yang sedang dalam proses tumbuh kembang sehingga segala perlakuan terhadap anak harus dapat menciptakan kondisi yang kondusif dalam rangka mendukung proses tumbuh kembang tersebut.

Pembinaan anak didik harus dapat memberi jaminan bahwa hakhak anak sebagaimana tertuang dalam UU No. 12 Tahun 1995 tentang Pemasyarakatan dapat dipenuhi. Dengan terpenuhinya hakhak anak akan dapat mendukung proses tumbuh kembang anak.

Pada beberapa instrument hukum yang mengatur tentang anak, telah memberi nuansa pemihakan terhadap anak, misalnya sebagaimana yang terkandung dalam Undang-Undang Nomor 11 Tahun 2012 tentang Sistem Peradilan Pidana Anak, mengatur tentang perlakuan terhadap terhadap anak yang melakukan pelanggaran hukum. Didalamnya diatur tentang tata cara penyidikan, penuntutan dan persidangan, dimana diberlakukan ketentuan khusus yaitu tidak mengenakan seragam seperti layaknya diberlakukan kepada orang dewasa. Hal itu untuk menjaga agar perkembangan psikologis anak tidak terganggu.

Undang-Undang 23 Tahun 2002 tentang Perlindungan Anak menyebutkan bahwa perlindungan anak adalah merupakan hak anak yang sangat esensial. Perlindungan ini meliputi perlindungan terhadap kekerasan, eksploitasi, diskriminasi dan penelantaran. ${ }^{10}$

Tujuan pemidanaan mengalami perkembangan sesuai dengan perkembangan paradigma pemidanaan yang dianut oleh suatu masyarakat. Dalam sejarah, tujuan (doktrin) pemidanaan telah mengalami beberapa fase perkembangan, yaitu: Pembalasan, Penjeraan, Rehabilitasi dan Re-Integrasi.

Doktrin pembalasan berasumsi bahwa konsep keadilan digambarkan sebagai suatu keseimbangan; mata dibayar mata, nyawa dibayar nyawa. Artinya bagi setiap pembunuhan maka akan dikatakan adil apabila si pembunuh di hukum mati.

\footnotetext{
${ }^{10}$ Sujanto, Adi dan Didin Sudirman. 2008. Pemasyarakatan. Vetlas Production, Jakarta, hlm 139
} 
Doktrin penjeraan berasumsi bahwa manusia itu bebas maka kesakitan yang paling hakiki adalah dicabut kebebasannya. Dengan demikian si pelaku kejahatan akan takut dan jera untuk melakukan perbuatan jahatnya. Namun yang menjadi masalah adalah pelaksanaan pidana hilang kebebasan bergerak melalui pemenjaraan pun tidak bebas masalah. Karena terbukti bahwa pemasukan orang ke dalam penjara ternyata dapat menimbulkan dampak prisonisasi. Prisonisasi adalah keadaan dimana terjadi suatu proses sosialisasi nilai-nilai masyarakat penjara yang dapat menimbulkan si narapidana dapat lebih buruk atau lebih jahat dibandingkan dengan sebelum ia masuk penjara.

Doktrin rehabilitasi berasumsi bahwa pada hakekatnya pelanggar hukum itu adalah orang memiliki kekurangan atau memiliki penyakit. Oleh sebab itu ia harus diperbaiki atau direhabilitasi.

Doktrin re-integrasi sosial berasumsi bahwa pelanggaran hukum terjadi bukan hanya karena kesalahan individu tetapi juga masyarakat mempunyai andil terhadap terjadinya pelanggaran hukum tersebut. Oleh karenanya masyarakat harus ikut bertanggung jawab dalam pelaksanaan pembinaan hukum. Harus diupayakan pemulihan hubungan yang harmonis antara pelanggar hukum dengan masyarakatnya. Konsep inilah yang melahirkan pemulihan hubungan hidup-kehidupan dan penghidupan dalam sistem pemasyarakatan. Hidup diartikan sebagai hubungan antara manusia dengan pencipta-Nya. Kehidupan diartikan sebagai hubungan antara manusia dengan lingkungannya, dalam kaitan ini manusia memanfaatkan alam untuk mempertahankan hidup dan kehidupannya.

Sejalan dengan Konsep Pemasyarakatan dan dikaitkan dengan pembinaan anak yang berhadapan dengan hukum, sekarang berhembus konsep yang dinamakan Restoratif Justice atau keadilan restoratif. Keadilan restoratif adalah suatu proses dimana semua pihak yang berhubungan dengan tindak pidana tertentu bersama-sama memecahkan masalah, dan bagaimana menangani akibat/implikasinya dimasa yang akan datang (Tony Marshall, diadopsi oleh Kelompok Kerja Peradilan Anak PBB). Adapun prinsip-prinsip dari Keadilan Reatoratif (seperti yang diuraikan oleh Apong Herlina, LSM Anak) adalah ${ }^{11}$ :

a. Membuat pelanggar hukum bertanggungjawab untuk memperbaiki kerugian yang ditimbulkan oleh kesalahnnya.

\footnotetext{
${ }^{11}$ Ibid, hlm 141
} 
b. Memberikan kesempatan kepada pelanggar untuk membuktikan kapasitas dan kualitasnya disamping mengatasi rasa bersalah secara konstruktif.

c. Melibatkan para korban, orang tua, keluarga besar, dan sekolah serta teman sebaya.

d. Menciptakan forum untuk bekerjasama dalam menyelesaikan masalah tersebut.

e. Menetapkan hubungan langsung dan nyata antara kesalahan dengan reaksi sosial yang formal.

f. Memperhatikan Hak Asasi Manusia.

Berdasarkan asumsi-asumsi tersebut diatas, maka secara internasional telah dikeluarkan berbagai konvensi yang menuntun setiap Negara anggota PBB untuk memperlakukan anak yang berhadapan dengan hukum, misalnya Beijing Rules (1985), Riyadh Guidelines (1990), Peraturan PBB tentang Perlindungan bagi Remaja yang Kehilangan Kebebasannya (1990) dan lain sebagainya.

\section{Pidana Pengawasan terhadap} Anak yang Berhadapan dengan Hukum ditinjau dari aspek Sistem Pemasyarakatan
Terkait dengan istilah sistem maka konten dari sistem tersebut selalu harus berisi hal-hal yang terkait dengan kebutuhan sistem. Kalau tidak, amaka sistem akan mengalami pembusukan (entrofi) serta lambaat laun akan mengalami kegagalan. Kebutuhan sistem meliputi: Pertama, sistem harus memiliki daya penyesuaian diri demi berlangsungya sistem tersebut yakni adanya dukungan sarana dan prasarana (aspek ekonomi). Kedua, sistem harus memiliki kekuasaann/kewenangan dalam mencapai tujuannya (aspek politik). Ketiga, sistem harus memiliki regulasi untuk mengintegrasikan semua sumber daya yang dimiliki demi efektifitas dan efisiensi berlangsungnya sistem tersebut (aspek sosial). Keempat, sistem harus memiliki daya untuk memelihara polapola demi keutuhan sistem melalui sistem budaya (reward and punishment).

Adapun nilai-nilai tersebut antara lain terdapat pada prinsip-prinsip pokok konsepsi Pemasyarakatan, yaitu:

a. Orang yang tersesat diayomi juga dengan memberikan kepadanya bekal hidup sebagai warga yang baik dan berguna dalam masyatakat.

Bekal hidup tidak hanya berupa financial dan material, tetapi yang lebih penting adalah mental, fisik (kesehatan), keahlian, ketrampilan, 
hingga orang nenpunyai kemampuan dan kemauan yang potensial dan efektif untuk menjadi warga yang baik, tidak melanggar hukum lagi, dan berguna dalam pembangunan Negara.

b. Menjatuhi pidana bukan tindakan balas dendam dari Negara.

Maka tidak boleh ada penyiksaan terhadap warga binaan pemasyarakatan baik yang merupakan tindakan, ucapan, cara perawatan ataupun penempatan. Satu-satunya derita yang dialami hendaknya hanya dihilangkan kemerdekaannya.

c. Tobat tidak dapat dicapai dengan penyiksaan melainkan dengan bimbingan.

Maka warga binaan pemasyarakatan harus ditanamkan pengertian menangani norma-norma hidup dan kehidupan, serta diberi kesempatan untuk merenungkan perbuatannya yang lampau.

d. Negara tidak berhak membuat seseorang lebih buruk/lebih jahat daripada sebelum ia masuk lembaga. Untuk itu harus diadakan pemisahan antara lain : a) yang residivist dan yang bukan, b) yang tindak pidana berat dan ringan, c) macam tindak pidana berat dan yang ringan, d) dewasa, dewasa muda, pemuda dan anak-anak, e) laki-laki dan wanita, f) orang terpidana dan orang tahanan/titipan.

e. Selama kehilangan kemerdekaan bergerak, warga binaan pemasyarakatan harus dikenalkan dengan masyarakat dan tidak boleh diasingkan daripadanya.

Warga binaan pemasyarakatan akan dibimbing ke luar lembaga (ditengahtengah masyarakat), itu merupakan kebutuhan dalam proses pemasyarakatan. Dan memang sistem pemasyarakatan didasarkan pada pembinaan yang "community centered" serta berdasarkan ineraktivitas dan interdisipliner approach antara unsur pegawai, masyarakat dan warga binaan pemasyarakatan.

f. Pekerjaan yang diberikan kepada warga binaan pemasyarakatan tidak boleh bersifat mengisi waktu, atau hanya diperuntukkan untuk kepentingan jawatan atau kepentingan Negara sewaktu saja.

Pekerjaan harus satu dengan pekerjaan di masyarakat dan ditujukan kepada pembangunan nasional. Maka harus ada integrasi pekerjaan warga binaan pemasyarakatan dengan 
pembangunan nasional. Potensi-

potensi kerja yang ada di lembaga harus dianggap sebagai yang integrasi dengan potensi pembangunan nasional.

g. Bimbingan dan pendidikan harus berdasarkan Pancasila

Maka pendidikan dan bimbingan itu harus berisikan asas-asas yang tercantum di dalamnya. Kepada warga binaan pemasyarakatan harus diberikan pendidikan agama serta diberi kesempatan dan bimbingan untuk melaksanakan ibadah dan ditanamkan jiwa kegotongroyongan, jiwa toleransi, jiwa kekeluargaan juga kekeluargaan antar bangsa-bangsa, ditanamkan jiwa rasa persatuan, kebangsaan Indonesia, jiwa musyawarah untuk mufakat yang positif, serta diikutkan dalam kegiatan-kegiatan untuk kepentingan bersama dan kepentingan umum.

h. Tiap orang adalah manusia dan harus diperlakukan sebagai manusia, meskipun ia telah tersesat.

Tidak boleh selalu ditunjukkan kepada warga binaan bahwa ia itu penjahat. Sebaliknya ia harus selalu merasa bahwa ia dipandang sebagai manusia.

i. Warga binaan pemasyarakatan hanya dijatuhi pidana hilang kemerdekaan
Walaupun selama dalam LAPAS warga binaan pemasyarakatan tetap mempunyai hak-hak lainnya sebagai layaknya manusia. Atau dengan kata lain, hak-hak keperdataannya tetap dilindungi, seperti hak mendapat perawatan kesehatan, makan, minum, pakaian, tempat tidur, latihan ketrampilan, olah raga, atau rekreasi.

j. Yang menjadi hambatan untuk melaksanakan sistem pemasyarakatan ialah warisan rumah-rumah penjara yang keadaannya menyedihkan yang sukar untuk disesuaikan dengan tugas pemasyarakatan, yang letaknya ditengah-tengah kota dengan tembok yang tinggi dan tebal.

Maka perlu kiranya mendirikan lembaga-lembaga baru yang sesuai dengan kebutuhan pelaksanaan program pembinaan, serta memindahkan lembaga-lembaga yang letaknya di tengah-tengah kota ke tempat yang sesuai dengan kebutuhan proses pemasyarakatan.

3. Pidana Pengawasan terhadap Anak yang Berhadapan dengan Hukum ditinjau dari Aspek Perlindungan Hukum maupun Syarat Kemanfaatan Hukum Pidana bagi Kesejahteraan Sosial (anak) 
Anak seyogianya dipandang sebagai aset berharga suatu bangsa dan Negara di masa mendatang yang harus dijaga dan dilindungi hak-haknya. Hal ini dikarenakan bagaimanapun juga di tangan anak-anak lahkemajuan suatu bangsa tersebut akan ditentukan.

Semakin modern suatu Negara, seharusnya semakin besar perhatiannya dalam menciptakan situasi yang kondusif bagi menumbuhkembangkan anak-anak dalam rangka perlindungan. Perlindungan yang diberikan Negara terhadap anak-anak meliputi aspek kehidupan, yaitu ekonomi, social, budaya, politik, hankam, maupun aspek hukum.

Menurut Barda Nawawi Arief, perlindungan hukum bagi anak dapat diartikan sebagai upaya perlindungan hukum terhadap berbagai kebebasan dan hak asasi anak (fundamental right and freedoms of children) serta berbagai kepentingan yang berhubungan dengan kesejahteraan anak. ${ }^{12}$

Kesejahteraan anak merupakan orientasi utama dari perlindungan hukum. Secara umum, kesejahteraan anak tersebut adalah suatu tata kehidupan dan penghidupan anak yang dapat

12 Barda Nawawi Arief, 1996. Beberapa Aspek Kebijakan Penegakan dan Pengembangan Hukum Pidana. Citra Aditya Bakti, Bandung, hlm 155 menjamin pertumbuhan dan perkembangannya dengan wajar, baik secara rohani, jasmani maupun social.

Berdasarkan prinsip nondiskrimiinasi, kesejahteraan merupakan hak setiap anak tanpa terkecuali. Maksudnya adalah bahwa setiap anak baik itu anak dalam keadaan normal maupun anak yang sedang bermasalah tetap mendapatkan prioritas yang sama dari pemerintah dan masyarakat dalam memperoleh kesejahteraan tersebut. ${ }^{13}$

Melihat berbagai macam peraturan yang ada, mulai dari Instrumen Internasional, antara lain Konvensi Hak Anak, Deklarasi Universal tentang Hakhak Asasi Manusia (DUHAM), ICPPR, Konvensi Menentang Penyiksaan dan Perlakuan atau Penghukuman Lain yang Kejam, Tidak Manusiawi atau Merendahkan Martabat Manusia, Standar Minimum bagi Perlakuan terhadap Narapidana, Aturan-aturan Tingkah Laku bagi Petugas Penegak Hukum, Peraturan Minimum Standar PBB mengenai Administrasi Peradilan Bagi Anak (Beijing Rules), Riyadhh Guidelines (Pedoman PBB dalam Rangka Pencegahan Tindak Pidana Remaja), Prinsip Perlindungan Semua Orang yang

\footnotetext{
${ }^{13}$ Nasir Djamil, M. 2013. Anak Bukan Untuk Dihukum. Sinar Grafika, Jakarta hlm 148
} 
di bawah Bentuk Penahanan apa pun atau Pemenjaraan, Peraturan PBB bagi perlindungan anak yang Kehilangan Kebebasannya. Di samping itu, juga ada Instrumen Nasional, antara lain UUD 1945, UU 39 Tahun 1999 tentang HAM, UU 23 Tahun 2002 tentang Perlindungan Anak, UU No. 12 Tahun 1995 tentang Pemasyarakatan, maka telah berhasil dirumuskan jaminan hak anak yang sedang mengikuti proses peradilan pidana dalam UU Sistem Peradilan Pidana Anak, antara lain:

a. diperlakukan secara manusiawi dengan memperhatikan kebutuhan sesuai dengan umurnya;

b. dipisahkan dari orang dewasa;

c. memperoleh bantuan hukum dan bantuan lain secara efektif;

d. melakukan kegiatan rekreasional;

e. bebas dari penyiksaan, penghukuman atau perlakuan lain yang kejam, tidak manusiawi, serta merendahkan derajat dan martabatnya;

f. tidak dijatuhi pidana mati atau pidana seumur hidup;

g. tidak tertangkap, ditahan, atau dipenjara, kecuali sebagai upaya terakhir dan dalam waktu yang paling singkat;

h. memperoleh keadilan di muka pengadilan anak yang objektif, tidak memihak, dan dalam sidang yang tertutup untuk umum;

i. tidak dipublikasikan identitasnya;

j. memperoleh pendampingan orang tua/wali dan orang yang dipercaya oleh anak;

k. memperoleh advokasi social;

1. memperolehh kehidupan pribadi;

m. memperoleh aksesibilitas, terutama bagi anak cacat;

n. memperoleh pendidikan;

o. memperoleh pelayanan kesehatan; dan

p. memperoleh hak lain sesuai dengan ketentuan peraturan perundangundangan.

Selain itu, khusus bagi anak yang sedang menjalani masa pidana berhak:

a. mendapat pengurangan masa pidana;

b. memperoleh asimilasi;

c. memperoleh cuti mengunjungi keluarga;

d. memperoleh pembebasan bersyarat;

e. memperoleh cuti menjelang bebas;

f. memperoleh cuti bersyarat;

g. memperoleh hal lain sesuai dengan ketentuan peratutan perundangundangan.

Secara tegas, jaminan hak asasi anak yang sudah dimasukkan dalam UU Sistem Peradilan Pidana Anak tersebut merupakan konsekuensi dari politik hukum perlindungan hak-hak anak. Hal yang penting di sini adalah bahwa 
sebenarnya anak bukanlah untuk dihukum, sehingga jaminan hak anak tersebut merupakan penjelmaan upaya memberikan pendidikan dan bimbingan kepada anak yang berkonflik dengan hukum.

Rumusan hak-hak anak yang ada dalam Pasal 3 dan pasal 4 UU Sistem Peradilan Pidana Anak berupaya untuk memberikan jaminan hukum sesuai dengan prinsip-prinsip perlindungan anak, yakni prinsip nondiskriminasi, prinsip kepentingan terbaik bagi anak, prinsip hak hidup, kelangsungan hidup dan perkembangan, serta prinsip penghargaan terhadap pendapat anak.

\section{PENUTUP}

\subsection{Simpulan}

Adapun simpulan dari uraian di atas :

1. Dalam kebijakan hukum pidana memformulasikan pidana pengawasan terhadap Anak yang Berhadapan dengan Hukum dalam sistem pembinaan didalam hukum positif Indonesia, terdiri atas 3 pokok bahasan: Pertama, Subtansi terhadap Anak yang Berhadapan dengan Hukum dalam kebijakan hukum di Indonesia Kedua, Penetapan sanksi/hukuman terhadap Anak yang Berhadapan dengan Hukum dalam kebijakan hukum pidana di Indonesia, Ketiga, pidana pengawasan terhadap Anak yang Berhadapan dengan Hukum dan relevansinya dengan teori pemidanaan dalam hukum pidana modern di Indonesia.

2. Pidana pengawasan terhadap Anak yang Berhadapan dengan Hukum sebagai tujuan pemidanaan yang integratif sesuai dengan ide dan sistem pemasyarakatan dibahas 3 pokok bahasan yaitu: Pertama, pidana pengawasan terhadap anal nakal ditinjau dari aspek teori pemidanaan yang integratif. Kedua, Pidana pengawasan terhadap Anak yang Berhadapan dengan Hukum ditinjau dari aspek sistem pemasyarakatan. Ketiga, Pidana pengawasan terhadap Anak yang Berhadapan dengan Hukum ditinjau dari aspek perlindungan hukum maupun syarat kemanfaatan hukum pidana bagi kesejahteraan sosial (anak).

\subsection{Saran}

1. Agar dalam penerapan sanksi/hukuman terhadap Anak yang Berhadapan dengan Hukum jangan sampai sanksi yang diterima oleh seorang anak dirasakan memberatkan 
dan berdampak negatif terhadap

perkembangan jiwanya.

2. Agar tujuan pemidanaan yang integrative sesuai dengan ide dan sistem pemasyarakatan dapat berjalan sesuai dengan yang diinginkan, diharapkan adanya sinergi antara pemerintah (Lembaga Pemasyarakatan Anak), orang tua dan masyarakat sekitar.

\section{DAFTAR PUSTAKA}

Arif Gosita, 1989. Masalah Perlindungan Anak. Akademika Pressindo, Jakarta

Barda Nawawi Arief, 1996. Beberapa Aspek Kebijakan Penegakan Hukum dan Pengembangan Hukum Pidana. Citra Aditya Bakti, Bandung

Muladi dan Barda Nawawi Arief, 1998. Teori-teori dan Kebijakan Pidana. Alumni Bandung

Muladi, 2002. Hak Asasi Manusia Politik dan Sistem Peradilan Pidana, Cetakan II. Badan Penerbit Universitas Diponegoro, Semarang

Nashriana, 2011. Perlindungan Hukum Pidana bagi anak di Indonesia. PT.RajaGrafindo Persada, Jakarta

Nasir Djamil, M. 2013. Anak Bukan Untuk Dihukum. Sinar Grafika, Jakarta

Padmo Wahyono, 1981. Bahan-bahan Pedoman Penghayatan dan Pengamalan Pancasila. Aksara Baru, Jakarta

Soejono Dirjosisworo, 1974. Kisah-Kisah Penjara di Berbagai Negara. Alumni, Bandung --------, 1982. Pathologi Sosial, Tarsito, Bandung

Soemitro, Ronny Hanitijo, 1994. Metodologi Penelitian Hukum dan Jurimetri. Ghalia Indonesia, Jakarta

Sudarto, 1983. Hukum dan Hukum Pidana. Alumni, Bandung

Sujatno, Adi dan Didin Sudirman. 2008. Pemasyarakatan Menjawab Tantangan Zaman. Vetlas Production, Jakarta

Suwantji Sisworahardjo, 1986. Hak-Hak Anak dalam Proses Peradilan Pidana. Yayasan LBH Indonesia dan Rajawali, Jakarta

\section{UNDANG - UNDANG}

Undang Undang Nomor 4 Tahun 1979 tentang Kesejahteraan Anak.

Undang Undang Nomor 8 Tahun 1981 tentang Kitab Undang Undang Hukum Acara Pidana.

Undang Undang Nomor 12 Tahun 1995 tentang Pemasyarakatan.

Undang Undang Nomor 23 Tahun 2002 tentang Perlindungan Anak.

Undang Undang Nomor 11 Tahun 2012 tentang Sistem Peradilan Pidana Anak.

Kitab Undang Undang Hukum Pidana (KUHP) 